\title{
RESEARCH
}

\section{SHH pathway inhibition is protumourigenic in adamantinomatous craniopharyngioma}

\author{
G Carreno1, J K R Boult², J Apps', J M Gonzalez-Meljem11,3, S Haston1, R Guiho1, C Stache1, L S Danielson4, A Koers4, \\ L M Smith4, A Virasami ${ }^{5}$, L Panousopoulos' ${ }^{1}$, M Buchfelder 6 , T S Jacques ${ }^{1,5}$, L Chesler ${ }^{4}$, S P Robinson ${ }^{2}$ and \\ J P Martinez-Barbera1
}

1Developmental Biology and Cancer Programme, Birth Defects Research Centre, Great Ormond Street Institute of Child Health, University College London, London, UK

2Division of Radiotherapy and Imaging, The Institute of Cancer Research, London, UK

${ }^{3}$ Basic Research Department, Instituto Nacional de Geriatría, Mexico City, Mexico

${ }^{4}$ Division of Clinical Studies and Cancer Therapeutics Division, Paediatric Solid Tumour Biology and Therapeutics Team, The Institute of Cancer Research, London, UK

5Department of Histopathology, Great Ormond Street Hospital for Children, NHS Foundation Trust, London, UK

${ }^{6}$ Department of Neurosurgery, University Hospital Erlangen, Erlangen, Germany

Correspondence should be addressed to J P Martinez-Barbera: j.martinez-barbera@ucl.ac.uk

\begin{abstract}
Pharmacological inhibition of the sonic hedgehog (SHH) pathway can be beneficial against certain cancers but detrimental in others. Adamantinomatous craniopharyngioma (ACP) is a relevant pituitary tumour, affecting children and adults, that is associated with high morbidity and increased mortality in long-term follow-up. We have previously demonstrated overactivation of the SHH pathway in both human and mouse ACP. Here, we show that this activation is ligand dependent and induced by the expression of $\mathrm{SHH}$ protein in a small proportion of tumour cells. We investigate the functional relevance of SHH signalling in ACP through MRI-guided preclinical studies using an ACP mouse model. Treatment with vismodegib, a clinically approved SHH pathway inhibitor, results in a significant reduction in median survival due to premature development of highly proliferative and vascularised undifferentiated tumours. Reinforcing the mouse data, SHH pathway inhibition in human ACP leads to a significant increase in tumour cell proliferation both ex vivo, in explant cultures, and in vivo, in a patient-derived xenograft model. Together, our results demonstrate a protumourigenic effect of vismodegibmediated SHH pathway inhibition in ACP.
\end{abstract}

$\begin{aligned} & \text { Key Words } \\ & \text { - craniopharyngioma } \\ & \text { - pituitary } \\ & \text { - SHH } \\ & \text { - vismodegib } \\ & \text { - tumour }\end{aligned}$

\section{Introduction}

Adamantinomatous craniopharyngiomas (ACPs) are benign tumours of the sellar region that are associated with high morbidity and increased mortality in longterm follow-up. They constitute the most common nonneuroepithelial brain tumour in children (peak diagnosis at 5-14 years) and can also develop in adults (peak diagnosis 50-74 years). ACPs display clinically aggressive behaviour by invading vital surrounding structures such as the hypothalamus and optic chiasm, which complicates surgical resection leading to severe postoperative sequelae. Currently, there are no targeted molecular treatments for these patients (Karavitaki \& Wass 2008, Muller et al. 2017) The majority of human ACPs carry somatic mutations in CTNNB1, which result in the expression of a degradation-resistant form of $\beta$-catenin and activation of the WNT/ $\beta$-catenin pathway (Sekine et al. 2002, 
Kato et al. 2004, Buslei et al. 2005, Brastianos et al. 2014, Apps et al. 2018).

The expression of functionally equivalent mutant $\beta$-catenin in either pituitary embryonic precursors

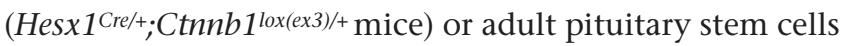
(Sox $2^{\text {CerERT2/+; }}$ Ctnnb1 $1^{\text {lox(ex3)/+ }}$ mice) results in the formation of tumours resembling human ACP (Gaston-Massuet et al. 2011, Andoniadou et al. 2013). In both models, tumoural pituitaries show the presence of $\beta$-catenin-accumulating cells forming clusters, which share a common molecular signature with those found in humans (Gonzalez-Meljem et al. 2017). Our initial studies revealed the upregulation of the sonic hedgehog $(\mathrm{SHH})$ pathway in both mouse and human ACP, a finding confirmed subsequently by independent research (Andoniadou et al. 2012, Gomes et al. 2015, Gump et al. 2015, Holsken et al. 2016). However, the biological function of the SHH pathway in ACP pathogenesis remains unknown to date.

The SHH pathway has been implicated in the pathogenesis of multiple cancers including medulloblastoma, basal cell carcinoma, breast, colon and pancreatic ductal adenocarcinoma (PDAC) (Rimkus et al. 2016). While SHH pathway inhibition has proven beneficial against basal cell carcinoma (Sekulic et al. 2012, 2017), it has proven detrimental in other cancers, such as PDAC, where enhanced tumour progression and aggressiveness was observed in both preclinical and clinical trials (Madden 2012, Catenacci et al. 2015). These discrepancies between favourable or unfavourable outcomes after SHH pathway inhibition prompted us to assess the functional relevance of the SHH pathway in human ACP. Our preclinical research demonstrates that inhibition of the $\mathrm{SHH}$ pathway using vismodegib is not beneficial and is therefore contraindicated in human patients.

\section{Materials and methods}

\section{Mice}

All experimental protocols were monitored and approved by The Institute of Cancer Research Animal Welfare and Ethical Review Body, in compliance with guidelines specified by the UK Home Office Animals (Scientific Procedures) Act 1986, the United Kingdom National Cancer Research Institute Guidelines for the Welfare of Animals in Cancer Research (Workman et al. 2010) and the ARRIVE guidelines (Karp et al. 2015). Animals were monitored daily and were killed at defined humane end points (i.e. prior to the mice showing signs of severe health deterioration or $20 \%$ weight loss). Patient-derived xenografts were generated as previously described (Stache et al. 2015). All mice were housed in compliance with the Home Office Code of Practice. Mice were kept on a 12-h light/darkness cycle and fed ad libitum with a complete pelleted mouse diet and with constant access to water.

Hes $\times 1^{\text {Cre/t }}$ mice have been previously described (Andoniadou et al. 2007). The line was maintained on a C57BL/6J background for over 50 generations. Heterozygotes were used for crosses with Ctnnb1lox(ex3)/+ mice (Harada et al. 1999) to obtain Hes $\times 1^{\text {Cre/t+ }}$ and Ctnnb1lox(ex3)/+ mice (Gaston-Massuet et al. 2011). For xenografts, we used $\mathrm{NIH} \mathrm{nu/nu}$ were bred in our local Biological Services Unit.

\section{Drug administration}

Four-week-old male Hes $\times 1^{\text {Cre } /+} ;$ Ctnnb1lox(ex3)/+ mice were administered vismodegib (Roche) or vehicle in $2 \%$ DMSO, 30\% PEG 300, 5\% Tween 80, dd $\mathrm{H}_{2} \mathrm{O}$ via oral gavage at a dose of $100 \mathrm{mg} / \mathrm{kg}$ of body weight twice a day (approximately 07:30 $\mathrm{h}$ and 16:00 h).

\section{Human samples}

Experiments using human samples were covered by the ethical approval 14 LO 2265 or the ethical approval of specific tissue banks. Human ACP samples were kindly provided by the GOSH Histopathology Department.

\section{Ex vivo culture of ACP human tumours}

Explant cultures were performed as previously described (Apps et al. 2018). Small pieces from three different human ACP tumours (approximately $1 \mathrm{~mm}^{3}$; four replicates per tumour) were placed on $0.2 \mu \mathrm{M}$ Whatman filters (SLS) in 24-well plates containing $500 \mu \mathrm{L}$ of media (DMEM-F12 (Gibco), 1\% Pen/Strep (Sigma) and 1\% FBS (PAA)) supplemented with either Vismodegib $100 \mu \mathrm{M}$ (Selleckchem) or vehicle (DMSO) and medium was changed every $24 \mathrm{~h}$. After $72 \mathrm{~h}$, tumour pieces were passed through a Qiashredder column (Qiagen) and processed for total RNA extraction using the RNeasy Micro kit (Qiagen). Approximately $1 \mu \mathrm{g}$ of total RNA was reversetranscribed to cDNA using the Transcriptor First-Strand cDNA Synthesis Kit and random hexamers (Roche).

\section{Magnetic resonance imaging}

Multi-slice $\mathrm{T}_{2}$-weighted images were acquired using a $7 \mathrm{~T}$ Bruker microimaging system with a $3 \mathrm{~cm}$ birdcage coil over

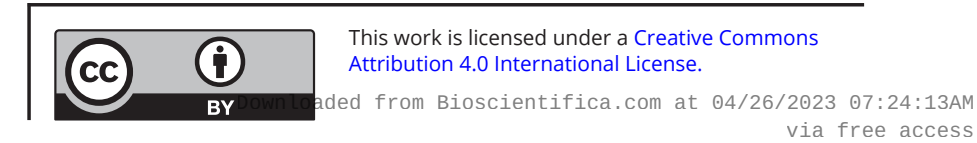


a $2.5 \mathrm{~cm}$ field-of-view (RARE; $\mathrm{T}_{\mathrm{R}}=4500 \mathrm{~ms}, \mathrm{~T}_{\mathrm{E}} \mathrm{eff}=36 \mathrm{~ms}$ ). MRI was performed on the final day of treatment and at least every 2 weeks thereafter, until mice presented with neurological symptoms or lost condition (Boult et al. 2018).

\section{Histology and immunostaining on histological sections}

Immunohistochemistry and immunofluorescence were carried out using the same antibodies, concentrations and retrieval conditions as previously described (Andoniadou et al. 2013, Gonzalez-Meljem et al. 2017, Apps et al. 2018). Immunostaining of $\mathrm{SHH}$ protein was also conducted as previously described (Carreno et al. 2017). Section immunostaining was performed as previously described (Andoniadou et al. 2012). Briefly, slides were de-waxed in HistoClear, re-hydrated from 100\% EtOH to double distilled MilliQ water and underwent antigen retrieval in an antigen retrieval unit (BioCare Medical Decloaking Chamber NXGEN) for $2 \mathrm{~min}$ at $95^{\circ} \mathrm{C}$. Slides were then washed in $1 \times$ PBT, which consists of $1 \times$ PBS and $0.1 \%$ Triton $\mathrm{X}-100$. Histological slides were then blocked for $1 \mathrm{~h}$ at RT in blocking buffer and 10\% heat inactivated sheep serum (HISS), blocking buffer contains 0.1\% Triton X-100, 0.15\% glycine, $2 \mathrm{mg} / \mathrm{mL}$ BSA in $1 \times$ PBS. SHH was visualised using the TSA Plus Fluorescein System (Perkin Elmer), following the manufacturer's protocol. Primary and secondary antibodies were diluted into blocking buffer and 1\% HISS. Sections were counter stained with 4',6-diamidino2-phenylindole (DAPI) for 5 min (1:10,000, Sigma) and mounted onto coverslips with VectaMount (Vector Laboratories). For immunohistochemical stainings, slides were first incubated with an Avidin-Biotinylated Peroxidase Complex (Vector). Chromogenic detection was then conducted by addition of 3,3'-diaminobenzidine (DAB, Vector) for 2-5 min and then counterstained with Mayer's hematoxylin (Sigma).

\section{Quantitative analysis of immunofluorescent stainings}

The proliferative and mitotic indexes were calculated as a percentage of the Ki67 positive or p-histone H3-positive cells out of the total of DAPI-stained nuclei, respectively. Cells were counted using ImageJ, a Gaussian filter was applied and the cell counter plugin was used. Endomucinpositive staining in pixels was analysed as a percentage of the total area using ImageJ.

\section{Quantitative reverse transcriptase PCR (qRT-PCR)}

Quantitative reverse transcriptase polymerase chain reaction (qRT-PCR) amplification was performed on murine anterior pituitaries and human tumour samples as previously described (Gonzalez-Meljem et al. 2017, Apps et al. 2018). RNA was extracted from tissues using the RNeasy Micro or Mini Kit (Qiagen). RNA was quantified using $1.2 \mu \mathrm{L}$ of extracted RNA on a NanoDrop 1000 Spectrophotometer. cDNA was retro-transcribed from $1 \mu \mathrm{g}$ of extracted RNA using the iScript Reverse Transcription Supermix for RT-qPCR kit (BioRad). Thermocycling conditions were performed according to manufacturer's instructions. qRT-PCR was performed using 64 iTaq Universal SYBR Green Supermix (BioRad), thermocycling conditions were performed according to manufacturer's instructions. Analysis was performed using CFX Manager BioRad software. Three microliters of the amplified product was run by gel electrophoresis in order to visualise correct product size. Relative quantitation of the target gene was performed against glyceraldehyde 3-phospate dehydrogenase (Gapdh) as the housekeeping gene in murine and human samples. The average $C t$ values were calculated for the control and test sample genes. $\Delta \mathrm{Ct}$ was calculated by subtracting the $\mathrm{Ct}$ of the housekeeping gene from the target gene Ct values for both test and control samples. $\Delta \Delta \mathrm{Ct}$ was then calculated as the ratio of expression between the test and control samples. Finally, the fold change was calculated by $2-\Delta \Delta \mathrm{Ct}$ for each sample. SHH, GLI1 and PTCH1 levels were measured using the Qiagen QuantiTect Primers (Cat. QT00205625, QT00060501, QT00075824). Murine Shh and Gli1 levels were measured with the Qiagen QuantiTect Primers (Cat. QT00122479, QT00173537).

\section{Murine pituitary adherent clonogenic cell culture}

Clonogenic assays were performed on murine tumoural pituitaries as described (Gaston-Massuet et al. 2011, Carreno et al. 2017, Haston et al. 2017). Pituitaries were dissected using aseptic forceps and the posterior pituitary was removed. After mincing with forceps, the remaining tissue was placed into $200 \mu \mathrm{L}$ of enzyme mix, which consisted of Hanks' Balanced Salt Solution (HBSS, Gibco), $0.5 \% \mathrm{w} / \mathrm{v}$ Collagenase (Worthington), $50 \mu \mathrm{g} / \mathrm{mL}$ DNAase I (Worthington), 1\% Fungizone and 0.1× trypsin (Sigma), for $4 \mathrm{~h}$ in a $37^{\circ} \mathrm{C}$ water bath. HBSS was added to make a final volume of $500 \mu \mathrm{L}$ post incubation and the solution was triturated into a single-cell suspension. Once single-cell

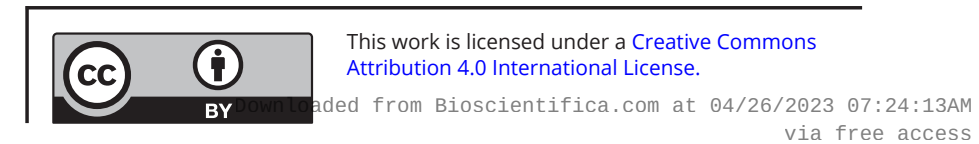


suspensions were achieved, $9.5 \mathrm{~mL}$ of HBSS was added and the cells spun down for $5 \mathrm{~min}$ at $200 \mathrm{~g}$. Cells were re-suspended in growth medium, which consisted of DMEM/F12, 5\% FCS, 1\% PenStrep, 20ng/mL human recombinant bFGF (R\&D Systems) and $50 \mathrm{ng} / \mathrm{mL}$ cholera toxin. Cells were plated at clonal density in a six-well plate at 2000, 4000 and 8000 cells per well. Fresh bFGF was added after 2 days, and medium was then changed on the third day and every 3 days after colony establishment. Colony counting was conducted after 7 days in culture. Colonies were washed with PBS and fixed for $20 \mathrm{~min}$ with 4\% PFA, washed again in PBS and stained with Harris haematoxylin for $15 \mathrm{~min}$ at room temperature.

\section{Xenografts}

Patient-derived xenograft (PDX) mice were generated as described (Stache et al. 2015). NIH nu/nu mice were anesthetised with $2 \%$ isoflurane and the top of the head was disinfected. An $\sim 1 \mathrm{~cm}$ incision was made to the skin of the head to expose the skull. The incision was treated with $10 \%$ xylocaine. Thrity percent $\mathrm{H}_{2} \mathrm{O}_{2}$ was applied to the skull to remove the periosteal membranes. A $1 \mathrm{~mm}$ in diameter hole was bored into the skull, $1 \mathrm{~mm}$ left and $1 \mathrm{~mm}$ posterior of the Bregma. Human ACP tumour tissue was dissected into $1-2 \mathrm{~mm}^{3}$ pieces, and these were inserted into the cortex using forceps. The skin was then sutured to close the wound. The surgical area was disinfected again. Mice were placed on a heated mat and monitored until recovery.

\section{Statistics}

Independent unpaired $t$-tests and one-way ANOVA were used to analyse the data from the qRT-PCR and proliferative assays using GraphPad Prism. Immunofluorescence was analysed using Image J. $P<0.05$ was considered statistically significant. The ' $n$ ' value indicated throughout the text refers to number of biological replicas, that is, different mice, pituitaries or tumour samples. Technical replicas, that is, number of repeats for the same sample, were three for the qRT-PCR experiments. In general, we have not performed power calculations to estimate the sample size. In most of the quantitative experiments, we have used at least three biological replicas, often 6 or more. Only in the xenotransplantation experiments, have we used two human tumours. Many of these experiments use embryos or mouse and human tumours, which are samples not readily available. For the preclinical trial, we performed a power calculation, based on pilot experiments. A total of 12 mice per group were decided to compensate for sample attrition.

\section{Results}

SHH protein is expressed in mouse and human ACP leading to the paracrine activation of the SHH pathway

The expression of SHH at the mRNA level in the $\beta$-catenin-accumulating cell clusters and activation of the SHH pathway in human ACP have been thoroughly documented (Andoniadou et al. 2012, Gomes et al. 2015, Gump et al. 2015, Holsken et al. 2016). However, the SHH protein has not been identified in human or mouse ACP. Double immunostaining revealed the co-localisation of $\beta$-catenin and $\mathrm{SHH}$ protein in clusters of both human and mouse ACP (Fig. 1A and B, respectively). qRT-PCR revealed that Shh mRNA expression was increased in Hes $\times 1^{\text {Crel+; }}$ Ctnnb1 ${ }^{\text {lox }(e x 3) /+}$ mutant mice relative to agematched Ctnnb1 1ox(ex3)/+ controls at one (134 \pm 1 -fold), four (125 \pm 1 -fold) and eight (68-fold) weeks of age $(n=3-5$ samples/group, $P<0.0001$, Student's $t$-test). The expression of the SHH pathway target gene Gli1 was also upregulated at all stages in mutant pituitaries compared to controls (1 week: $15.3 \pm 0.2$-fold $P=0.018$; 4 weeks: $8.7 \pm 0.1$-fold; 8 weeks: $4.9 \pm 0.3$-fold; $n=3-5$ samples/group; $P<0.0001$; Student's $t$-test) (Fig. 1C). Note that a similar decreasing trend in Gli1 and Shh mRNA expression was observed over time (Fig. 1C). Since mutations in the components of the SHH pathway have not been identified in humans (Brastianos et al. 2014, Apps et al. 2018) or mouse ACP (Gonzalez-Meljem et al. 2017), our data suggest that the SHH pathway is activated in ACP in a ligand-dependent manner.

\section{Inhibition of the SHH pathway in a genetically modified murine model of ACP results in reduced survival and increased tumourigenesis}

To assess the role of the SHH pathway in the pathogenesis of ACP, we performed a MRI-guided preclinical trial using the smoothened (SMO) inhibitor vismodegib in the Hes $\times 1^{\text {Crel+; }}$ Ctnnb $1^{\text {lox }(e x 3) /+}$ ACP mouse model. Clinical trials have demonstrated that treatment with vismodegib results in long-term responses in patients with advanced basal cell carcinoma (Sekulic et al. 2012, 2017), and this inhibitor is currently being used in numerous ongoing clinical trials for other human cancers (Rimkus et al. 2016).

This work is licensed under a Creative Commons Attribution 4.0 International License. ded from Bioscientifica.com at 04/26/2023 07:24:13AM 
Pharmacokinetic studies in mice have shown that serum levels of vismodegib decrease after $12 \mathrm{~h}$ and suggested that a twice-a-day dosing regimen leads to more permanent pathway inhibition (Wong et al. 2011). An administration dose of $100 \mathrm{mg} / \mathrm{kg}$ of body weight was chosen as it is the highest non-toxic dose identified in the literature (Wong et al. 2011). A dosing regimen of twice a day for 7 days was chosen as it was hypothesised that any pharmacological effect on the SHH pathway would be evident after 7 days. This dosing regimen revealed an overall reduction in relative Gli1 mRNA levels in the vismodegib-treated tumoural pituitaries compared to vehicle-treated control pituitaries, which did not reach significance (vehicle: 2.5 -fold, vismodegib: 1.5 -fold, $n=8$; $P=0.35$, ANOVA) (Fig. 1D). We noted a high degree of variability in Gli1 expression levels in the vehicle-control group as well as untreated Hes $\times 1^{\text {Cre/+; }}$ Ctnnb1 1 lox(ex3)/+ mice (2.1-fold relative to Ctnnb1 $1^{\operatorname{lox}(\text { ex } 3) /+}$ controls, $n=7$ mice), with some animals showing much higher Gli1 levels than others, suggesting a similarly inherent heterogeneity in the ACP mouse model to that reported in human ACP (Gomes et al. 2015). Gli1 expression mRNA levels were lower and more uniform with vismodegib treatment. We did not evaluate GLI1 expression at the protein level.

For the preclinical trial, Hes $\times 1^{\mathrm{Cre} /+} ;$ Ctnnb $1^{\text {lox(ex3)/+ }}$ mice were dosed twice a day with $100 \mathrm{mg} / \mathrm{kg}$ of body weight of vismodegib or vehicle (11 and 12 mice, respectively) for a total of 56 doses over 28 days (the maximum allowed by UK animal welfare authorities) (Fig. 1E). Treated mice were monitored by MRI and killed at a defined humane endpoint (i.e. prior to the mice showing signs of severe health deterioration or $20 \%$ weight loss). Surprisingly, a significant decrease in survival was observed in the vismodegib-treated animals in comparison with vehicletreated controls (11.9 weeks vs 33.3 weeks; $P=0.049$, log-rank test) (Fig. 1F).

$\mathrm{T}_{2}$-weighted MRI throughout the trial up until each humane end point for both treated and vehicle groups demonstrated no significant differences in tumour phenotype and size of total and solid tumour volume (Fig. 2A). In other words, the vismodegib-treated mice did not develop larger tumours; at the humane end point, tumours were similar in size. MRI revealed tumour enlargement and heterogeneity in both groups prior to the development of hyperintense cysts, expansion of a solid portion of the tumour and presentation of hypointense haemorrhagic regions, consistent with our previous imaging studies (Boult et al. 2018). Furthermore histologically, tumours showed no gross morphological differences between the groups (Fig. 2B). However, the MRI data revealed that the doubling time of the solid component of the tumours was shorter in vismodegib-treated tumours compared with controls (vismodegib: $8.1 \pm 1$ days; $n=6$; vehicle: $15.3 \pm 3$ days; $n=7 ; P=0.044$; Student's $t$-test) (Fig. 2F). In agreement with these observations, the Ki67 proliferative index was increased in the vismodegibtreated group $(41.3 \pm 7 \%, n=10)$ compared with controls $(27.4 \pm 5.5 \%, n=9) \quad(P=0.0002$, Student's $t$ test) (Fig. 2C). The mitotic index, measured by phospho-Histone H3 (pHH3) immunofluorescence, was also increased in the vismodegib-treated group (vismodegib: $6.5 \pm 3 \%$; $n=10$; vehicle: $3.6 \pm 0.8 \% ; n=9 ; P=0.016$; Student's $t$-test) (Fig. 2D). Vismodegib treatment led to increased vasculogenesis, as assessed by immunofluorescence staining against the endothelial marker endomucin (fluorescent area: $7.8 \pm 2 \%$ in vismodegib-treated group; $5.4 \pm 1.4 \%$ in control group; $n=6$; $P=0.0319$; Student's $t$-test) (Fig. 2E). Together, these results suggest that chemical SHH pathway inhibition

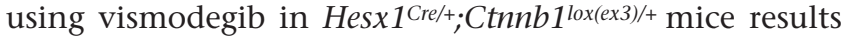
in the formation of aggressive tumours.

\section{Vismodegib-treated Hesx1 ${ }^{\mathrm{Cre} /+;}$;Ctnnb1/ox(ex3)/+ mouse pituitaries develop tumours prematurely and show increased numbers of clonogenic cells}

We hypothesised that inhibiting the SHH pathway could lead to an increase in the number of cells with clonogenic tumour cells within, potentially tumour-initiating cells. Four-week-old Hesx $1^{\mathrm{Cre} /+} ;$ Ctnnb1lox(ex3)/+ mice were treated with either vismodegib $(100 \mathrm{mg} / \mathrm{kg}$ of body weight $)$ or vehicle for 7 days, after which tumoural pituitaries were dissected and subjected to either histological analysis or assessment of the clonogenic potential as previously described (Gaston-Massuet et al. 2011, Andoniadou et al. 2013) (Fig. 3A). H\&E staining identified tumour lesions in vismodegib-treated Hes $\times 1^{\text {Cre/+; }}$ Ctnnb $1^{\text {lox(ex3)/+ }}$ pituitaries (3/3 pituitaries, Fig. 3B, arrows), which were not present in the vehicle-treated mice ( $0 / 3$ pituitaries). These tumoural lesions were synaptophysin negative, suggesting loss of differentiation into hormone-producing cells (Fig. 3C), consistent with previous observations in mouse and human ACP. Furthermore, vismodegib-treated tumoural pituitaries showed a higher Ki67 proliferative index compared with controls (controls: $3 \pm 1.2 \%$; vismodegib: $8.8 \pm 1.0 \% ; n=3 ; P=0.0037$; Student's $t$-test) (Fig. 3D). We have previously shown the expansion of clonogenic SOX2-positive tumour cells in the Hes $\times 1^{\text {Cre/+; }}$ Ctnnb $11^{\text {lox(ex3)/+ }}$ mice (Gaston-Massuet et al. 2011, Andoniadou et al. 2013). https://erc.bioscientifica.com https://doi.org/10.1530/ERC-18-0538
(C) 2019 The authors Published by Bioscientifica Ltd. Printed in Great Britain
This work is licensed under a Creative Commons Attribution 4.0 International License. ded from Bioscientifica.com at 04/26/2023 07:24:13AM 
B

A

Human ACP

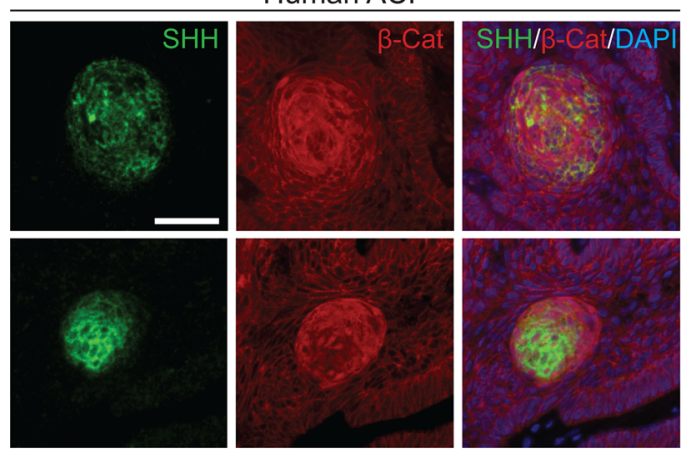

C

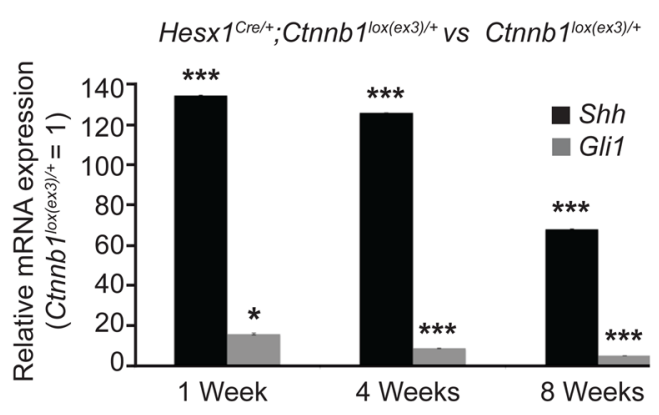

D

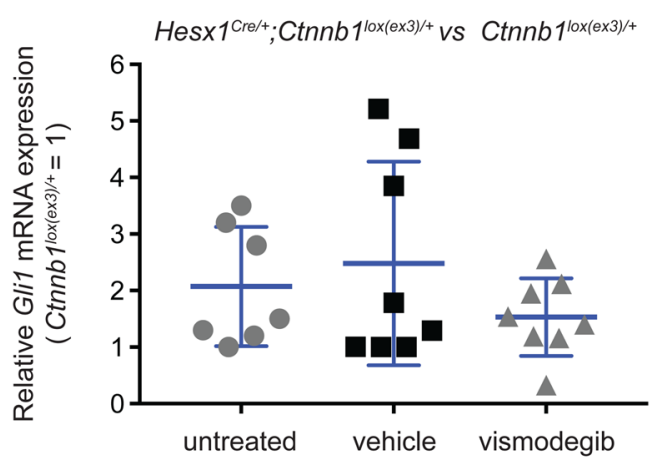

Hesx $1^{\mathrm{Cre} /+} ;$ Ctnnb $^{10 \times(e \times 3) /+}$

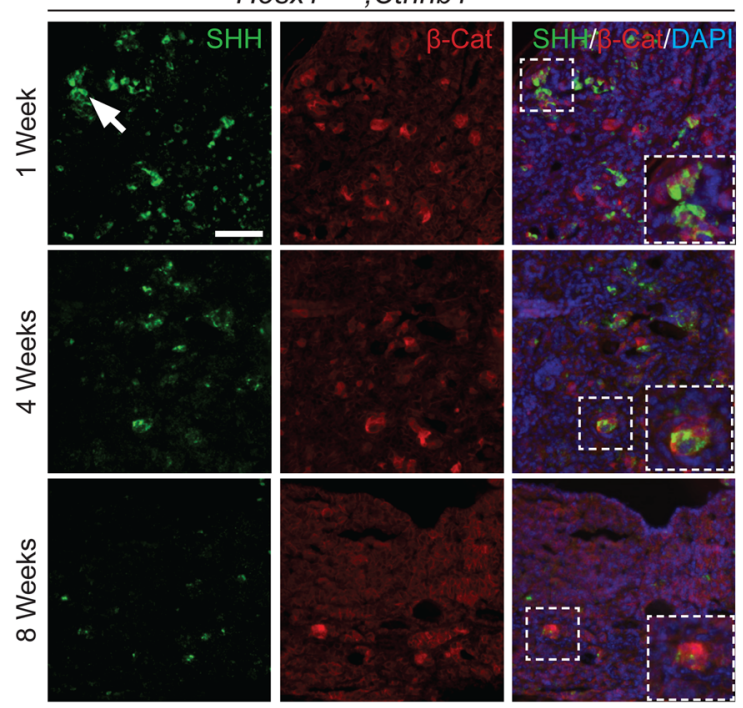

E

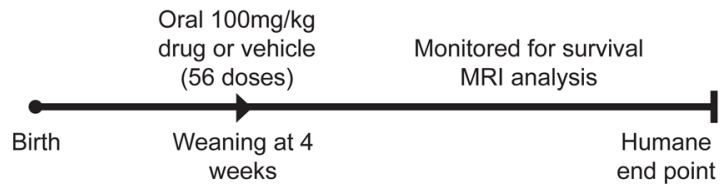

$\mathrm{F}$

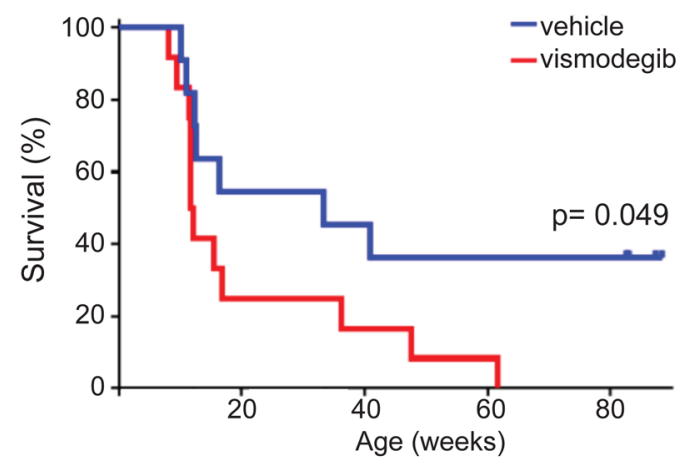

\section{Figure 1}

Inhibition of the SHH pathway in Hesx $1^{\mathrm{Cre} /+} ;$ Ctnnb1 1lox(ex3)/+ mice, a murine model of human adamantinomatous craniopharyngioma (ACP), results in reduced median survival. (A) Double immunofluorescence on formalin-fixed paraffin-embedded (FFPE) histological sections of human ACP showing the expression of SHH in the $\beta$-catenin-accumulating cell clusters. Scale bar: $25 \mu \mathrm{m}$. (B) Double immunofluorescence on FFPE histological sections of

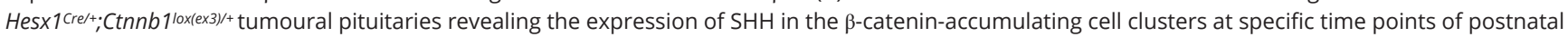
life. Note the overall reduction in SHH staining from 1 to 8 weeks of age. Scale bar: $50 \mu \mathrm{m}$. (C) qRT-PCR analysis showing the up-regulation of Shh and the target pathway gene Gli1 in the tumoural pituitaries of the Hesx $1^{\text {Cre/+; }}$ Ctnnb1 1lox(ex3)/+ ACP mouse model compared with Ctnnb1/ox(ex3)/+ Controls at specific ages (Shh: 1 week, 134-fold; 4 weeks, 125-fold; 8 weeks, 68-fold; Gli1: 1 week, 15.3-fold, $P=0.018 ; 4$ weeks, 8.7-fold, $P<0.0001 ; 8$ weeks, 4.9 -fold, $P<0.0001$ ( $n=3-5$ tumoural pituitaries per time point, Student's $t$-test). (D) qRT-PCR analysis of Gli1 expression levels in Hesx 1 Cre/+;Ctnnb1/oxex3/+ tumoural and Ctnnb1lox(ex3)/+ control pituitaries treated twice daily with vismodegib (100 mg/kg) for 1 week in comparison with vehicle-treated and untreated mice. There is an overall reduction in Gli1 expression levels upon vismodegib treatment, which does not reach significance possibly due to the marked variability in Gli1 expression levels in the untreated and vehicle treated controls (untreated: 2.1 -fold, $n=7$ mice; vehicle: 2.5 -fold, $n=8$ mice; vismodegib: 1.5 -fold, $n=8$

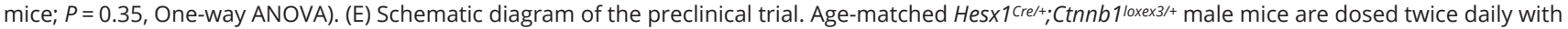
100 mg/kg vismodegib (11 mice) or vehicle (12 mice) for 28 days starting around 4-5 weeks of age (56 doses). At the end of treatment, mice are left untreated and monitored by MRI every 2 weeks and at the humane end point. (F) Kaplan-Meier analysis showing a reduction in median survival in the vismodegib-treated (11.9 weeks, $n=11$, red line) relative to the vehicle-treated mice (33.3 weeks, $n=12$, blue line; $P=0.049$, Mantel-Cox (log-rank) test). Data represent the mean \pm S.D.

https://erc.bioscientifica.com https://doi.org/10.1530/ERC-18-0538 (c) 2019 The authors Published by Bioscientifica Ltd. Printed in Great Britain
This work is licensed under a Creative Commons Attribution 4.0 International License. 
A
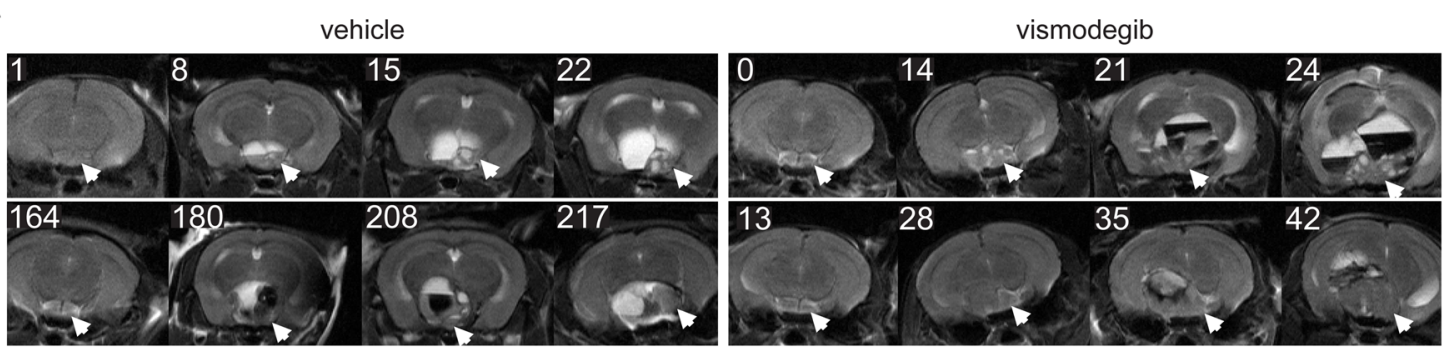

B

$\mathrm{H} \& \mathrm{E}$

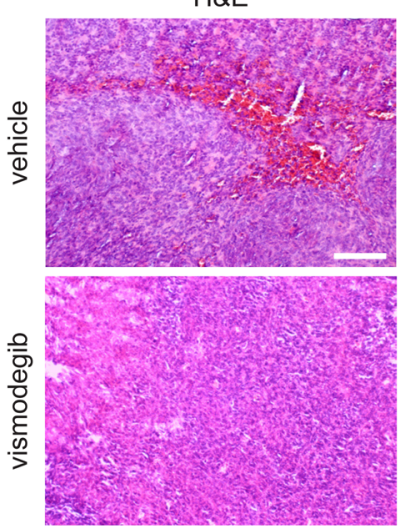

C

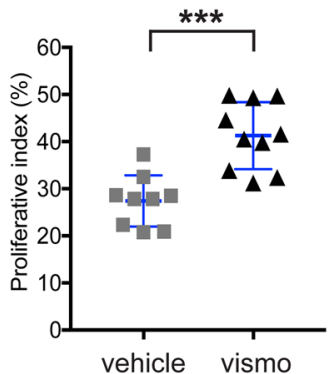

Ki67/DAP|
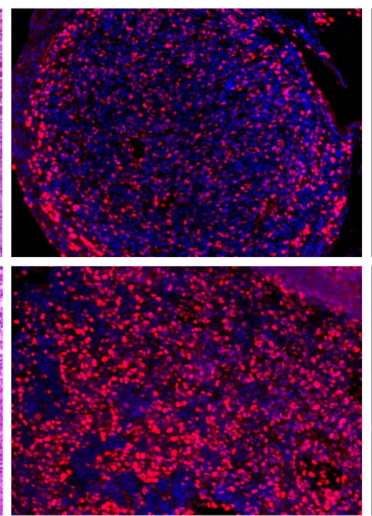

D

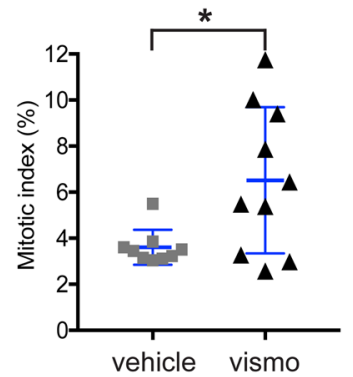

pHH3/DAPI
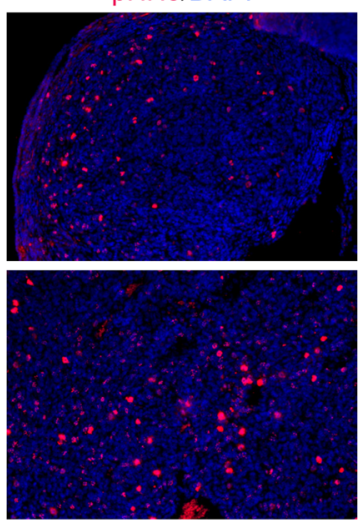

E

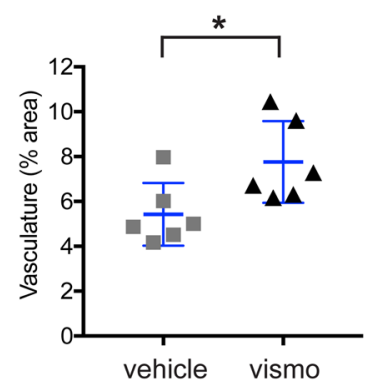

EMCN/DAPI

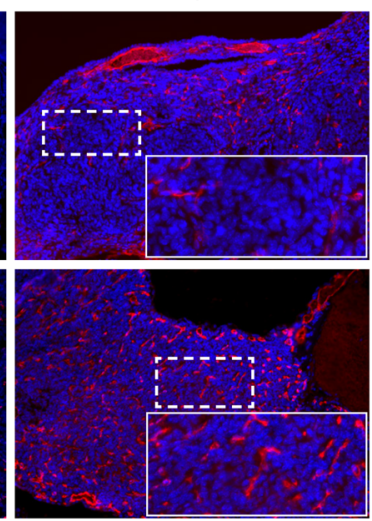

F

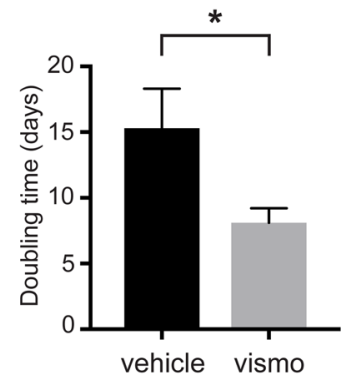

\section{Figure 2}

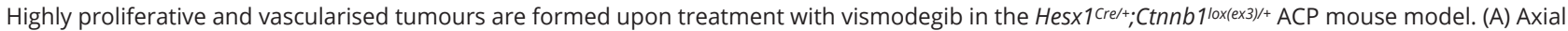
T2-weighted MRI scans of vismodegib and vehicle-treated Hesx1Cre/+;Ctnnb1/ox(ex3)/+ mice at the level of the brain (two examples of each are shown, labels indicate days after the end of treatment). Note the expansion of the pituitary to form a solid tumour component (arrows) and the development of hyperintense cysts and hypointense haemorrhagic regions in both vehicle and vismodegib-treated groups. (B) Hematoxylin-eosin (H\&E) staining of FFPE histological sections of Hesx $1_{C r e /+;}$ Ctnnb1loxex3/+ tumours showing similar histology between experimental groups. Immunofluorescence revealing the increased expression of Ki67 (proliferative marker), pHH3 (mitotic marker) and Endomucin (endothelial marker) in vismodegib-treated tumours compared with the vehicle-treated controls. Scale bar: $50 \mu \mathrm{m}$. (C) (vehicle: $27.4 \pm 5.5 \%, n=9$ tumours; vismodegib: $41.3 \pm 7 . \%, n=10$ tumours; $P=0.0002$, Student's t-test, 15,600 DAPI +ve nuclei counted). (D) The mitotic index (fraction of pHH3+ve cells out of total DAPI+ve cells) is elevated upon vismodegib treatment (vehicle: $3.6 \pm 0.8 \%, n=9$ tumours; vismodegib: $6.5 \pm 3 \% ; n=10$ tumours; $P=0.016$, Student's $t$-test, 16,700 DAPI +ve nuclei counted). (E) Vasculature is increased in the vismodegib-treated group as assessed by immunofluorescence against Endomucin (total fluorescent area: vehicle: $5.4 \pm 1.4 \%$; vismodegib: $7.8 \pm 2 \% ; n=6$ tumours per group; $P=0.0319$, Student's $t$-test). (F) Doubling time of the solid component of the tumours, as calculated from contiguous MRI scans, is reduced by $47 \%$ upon vismodegib treatment (vehicle: $15.3 \pm 3$ days, $n=7$ tumours; vismodegib: $8.1 \pm 1$ days, $n=6$ tumours; $P=0.044$, Student's $t$-test). Data represent mean \pm S.D.

Immunofluorescent staining revealed an elevation in SOX2 expression in the vismodegib-treated Hes $\times 1^{\mathrm{Cre} /+}$;Ctnnb1 $1^{\text {lox }(e \times 3) /+}$ pituitaries compared with vehicletreated controls. Moreover, dissociation of tumoural pituitaries into single-cell suspensions and culture in stem cell-promoting media showed a significant increase in the numbers of colonies in vismodegib-treated animals relative to controls (vehicle: 2597 \pm 98 ; vismodegib: $4924 \pm 167$; $n=3 ; P=0.0003$; Student's $t$-test) (Fig. 3E and F). Currently, there is no ACP primary cell culture that maintains the https://erc.bioscientifica.com https://doi.org/10.1530/ERC-18-0538 (c) 2019 The authors Published by Bioscientifica Ltd. Printed in Great Britain
This work is licensed under a Creative Commons Attribution 4.0 International License. 
A

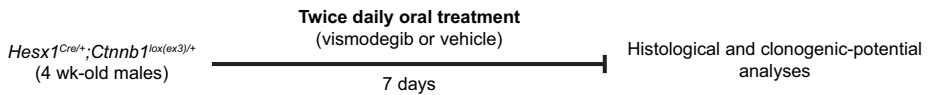

B

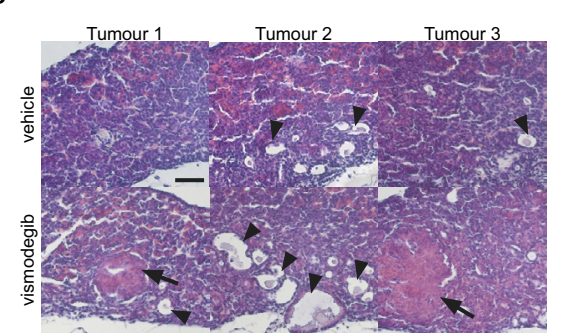

D

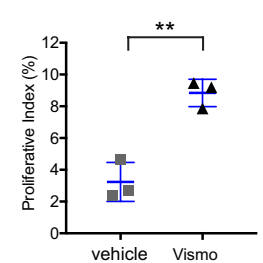

E

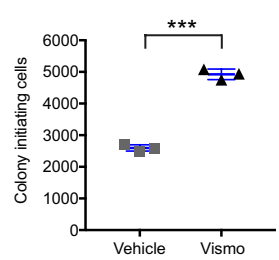

C

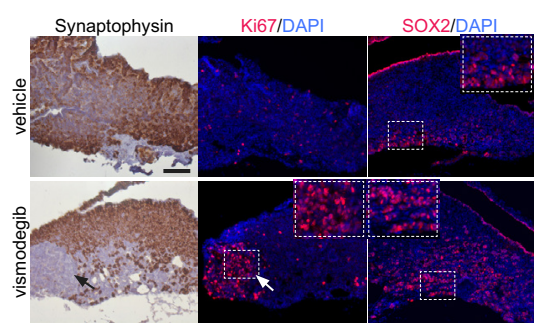

F
G

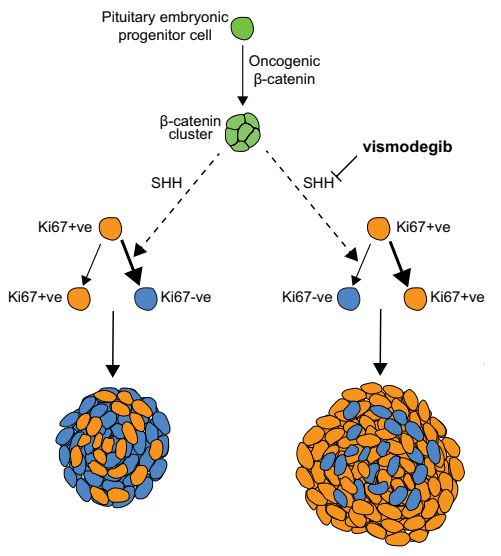

\section{Figure 3}

Vismodegib treatment results in higher numbers of clonogenic cells and premature formation of tumours. (A) Diagram of the experimental approach. Four-week old Hesx $1^{\mathrm{Cre} /+} ;$ Ctnnb $1^{10 \times \times \times 3 /+}$ male mice are dose twice daily with either vismodegib $(100 \mathrm{mg} / \mathrm{kg}$ ) or vehicle for 1 week, after which pituitaries are dissected and analysed both histologically and in a clonogenic assay. (B) H\&E staining on FFPE histological sections of vehicle and vismodegib -treated mice showing the presence of large tumoural lesions (arrows) and cysts (arrowheads) in vismodegib-treated animals. The control pituitaries show smaller cysts (arrowheads) and no tumour lesions are detectable ( $n=3$ pituitaries per group). This is in agreement with our previous observations of a latency period of around 17 weeks for tumour formation (Boult et al. 2018). Scale bar: $100 \mu \mathrm{m}$. (C) The premature tumour lesions are Synaptophysin-ve (black arrow) by immunohistochemistry, and highly proliferative, as assessed by immnufluorescence against Ki67 (white arrow). (D) Quantitative analysis demonstrates the higher Ki67 proliferative index upon vismodegib treatment (vehicle: $3.2 \pm 1.2 \%$; vismodegib: $8.8 \pm 1.0 \%, n=3$ pituitaries per group; $P=0.0029$, Student's $t$-test, vehicle $=15,213$, vismodegib $=13,300$ DAPI +ve nuclei counted). Scale bar: $200 \mu \mathrm{m}$. (E) Quantification of the clonogenic potential of pituitaries from mice treated with either vehicle or vismodegib ( $n=3$ pituitaries per group). Note that vismodegib treatment results in drastic increase in clonogenic potential of nearly 90\% relative to the vehicle controls (vehicle: $2597 \pm 98$ colonies; vismodegib: $4924 \pm 167$ colonies, $n=3$ pituitaries per group; $P=0.0003$, Student's $t$-test). (F) Representative examples of plates seeded with 2000,4000 and 8000 pituitary cells from vehicle and

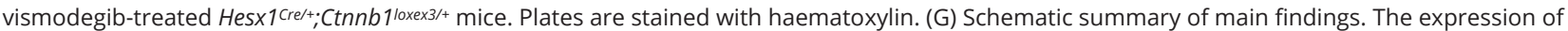
oncogenic $\beta$-catenin in Hesx 1 Crel+; Ctnnb 1 loxex3/+ mice results in formation of $\beta$-catenin-accumulating cell clusters, which secrete SHH and activate the pathway in surrounding tumour cells inducing a more quiescent phenotype characterised by exit of a proliferative, Ki67+ve state. vismodegib-mediated inhibition of the SHH pathway leads to more proliferative and aggressive tumours. All graph bars represent mean \pm S.D.

mutation sustaining cells throughout passages. Together, these results suggest that the inhibition of the $\mathrm{SHH}$ pathway leads to an increase in clonogenic tumour cells, with increased proliferative capacity, which promotes the development of premature tumour lesions (Fig. 3G).

\section{Inhibition of the SHH pathway in human ACP tumours leads to increased proliferation}

Finally, we assessed the relevance of the murine studies in human ACP. Small pieces of human ACP tumours (1-2 $\left.\mathrm{mm}^{3}\right)$ were cultured ex vivo in the presence of vismodegib or vehicle, and after 3 days, the tissue was analysed (Fig. 4A) (Apps et al. 2018). Vismodegib treatment resulted in the overall downregulation of the $\mathrm{SHH}$ pathway, as assessed by qRT-PCR against GLI1, PTCH1 and SHH (Fig. 4B), and the concomitant increase of the proliferative index (38.7 $\pm 12 \%)$ relative to the vehicle controls $(5.1 \pm 3 \% ; n=3$; $P=0.0085$; Student's $t$-test) (Fig. $4 \mathrm{C}$ and D). To assess the effects of vismodegib in vivo, small fragments of human ACP were engrafted into the brains of 20 immunodeficient mice (Fig. 4E). After 3 months, mice were divided into two groups (10 mice/group) and administered $100 \mathrm{mg} / \mathrm{kg}$ of body weight of vismodegib or vehicle, twice a day for 3 weeks, after which brains were collected for histological analysis. Immunofluorescent staining revealed a significant increase in the Ki67 proliferative index in vismodegibtreated xenograft mice $(12.7 \pm 2 \%, n=4)$ relative to the vehicle-treated controls $(1.8 \pm 0.5 \%, n=3) \quad(P<0.0001$, Student's t-test) (Fig. 3F and G). https://erc.bioscientifica.com https://doi.org/10.1530/ERC-18-0538 (c) 2019 The authors Published by Bioscientifica Ltd. Printed in Great Britain
This work is licensed under a Creative Commons Attribution 4.0 International License. ded from Bioscientifica.com at 04/26/2023 07:24:13AM 
A

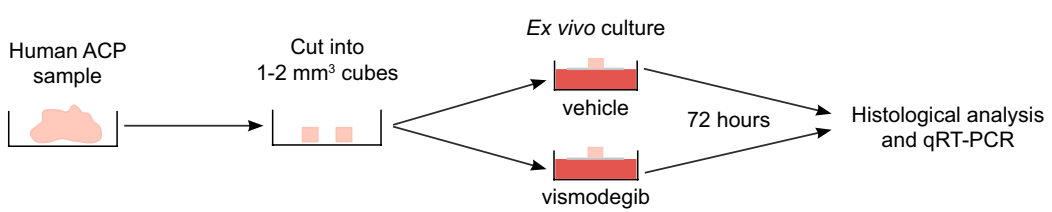

B

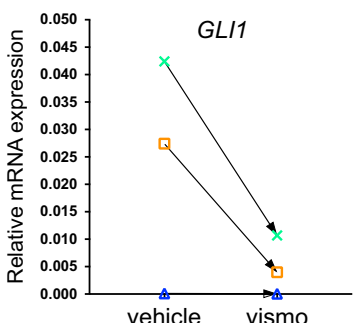

C

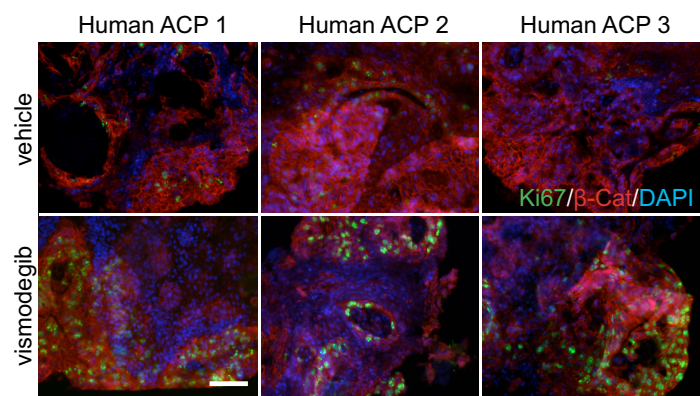

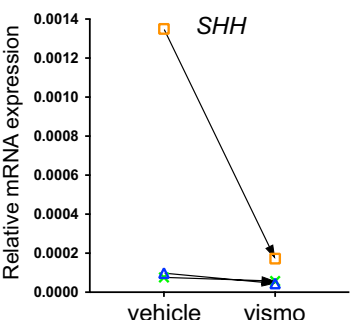

D

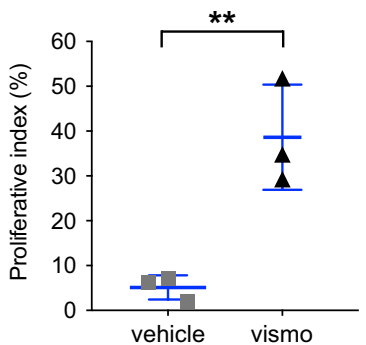

E

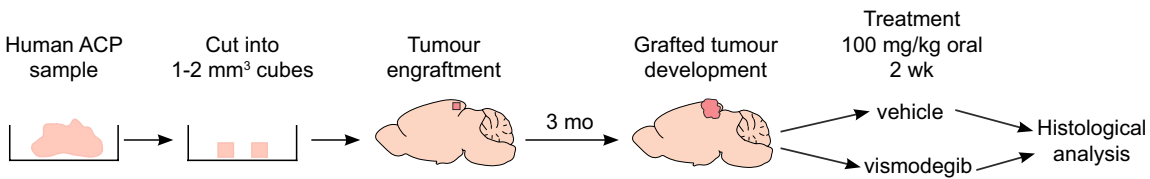

F

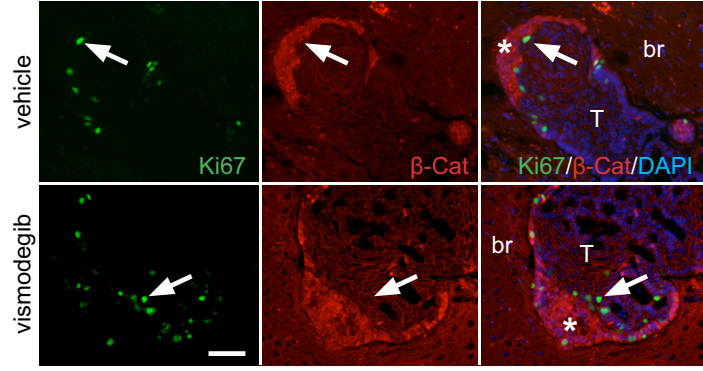

G

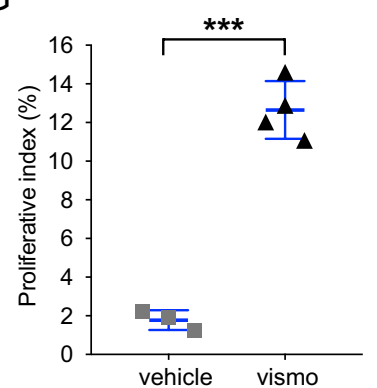

\section{Figure 4}

Inhibition of the SHH pathway leads to increased tumour cell proliferation in both explant cultures and xenograft models of human ACP. (A) Schematic diagram of the explant culture experiments. Three ACP tumour samples were cut into 1-2 $\mathrm{mm}^{3}$ cubes and cultured in the presence of vismodegib $(100 \mu \mathrm{M})$ or vehicle (DMSO). Four biological replicates were performed for each analysis (i.e. four pieces of tumours per treatment). (B) qRT-PCR analysis showing the overall inhibition of the SHH pathway as assessed by a variable reduction in GLI1, PTCH1 and SHH expression upon vismodegib treatment in three human ACP tumours. One sample did not show reduction of GLI1, but both PTCH1 and SHH expression were reduced. (C) Double immunofluorescence on FFPE histological sections showing increased expression of Ki67+ve in the human ACP explants cultured in the presence of vismodegib relative to the DMSO-treated controls. Scale bar: $25 \mu \mathrm{m}$. (D) Quantitative analysis revealing a higher Ki67+ve proliferative index in vismodegib compared with vehicle-treated explants (vehicle: $5.1 \pm 3 \%$; vismodegib: $38.7 \pm 12 \% ; n=3$ tumours per group; $P=0.0085$, Student's $t$-test, 10,037 DAPI +ve nuclei counted). (E) Schematic diagram of the human ACP xenograft experiments. Two human ACP tumours were cut into $1-2 \mathrm{~mm}^{3}$ and implanted into the cortex of 20 immunosuppressed mice (11 animals with tumour 1 and 9 with tumour 2$)$. Three months later, mice were randomised into two groups of 10 mice each and dosed twice daily with $100 \mathrm{mg} / \mathrm{kg}$ vismodegib or vehicle for 21 days, after which brains were dissected and analysed histologically. (F) Double immunofluorescent staining revealing the presence of Ki67+ve cells (arrows) in the proximity of $\beta$-catenin-accumulating cell clusters (asterisks) in both vismodegib and vehicle-treated xenografted human ACP tumours. Scale bar: $25 \mu \mathrm{m}$. (G) Quantitative analysis showing an elevation of the Ki67 proliferative index in the xenografted tumours upon treatment with vismodegib (vehicle: $1.8 \pm 0.5 \%, n=3$ tumour-bearing mice; vismodegib: $12.7 \pm 2 \%$, $n=4$ tumour-bearing mice; $P<0.0001$, Student's $t$-test, $2332 \mathrm{DAPI}+$ ve nuclei counted). All graph bars represent mean \pm S.D.

https://erc.bioscientifica.com https://doi.org/10.1530/ERC-18-0538 (c) 2019 The authors Published by Bioscientifica Ltd. Printed in Great Britain
This work is licensed under a Creative Commons Attribution 4.0 International License. 


\section{Discussion}

The main highlight of this research is the demonstration that the inhibition of the SHH pathway using vismodegib, a well-established SMO inhibitor used in the clinic (De Smaele et al. 2010), results in premature tumour formation and increased tumour cell proliferation in both genetically engineered and patient-derived xenograft mouse models. These data suggest that the use of vismodegib and potentially other SMO inhibitors is contraindicated in ACP patients.

The activation of the SHH pathway in human ACP was initially documented from research in the Hes $\times 1{ }^{\text {Crel }} ;$; Ctnnb1 1 loxex $3 /++$ mouse model of ACP. The presence of mRNA expression was demonstrated in five human ACP tumours (Andoniadou et al. 2012). These results were extended further in a larger cohort of tumours by Gomes et al., who revealed the expression of GLI1, GLI3, SUFU and SMO in human ACP at the protein level (Gomes et al. 2015). More recently, the activation of the SHH pathway has been demonstrated in gene expression analyses of ACP (Holsken et al. 2016, Donson et al. 2017, Apps et al. 2018). Mutations in components of the SHH pathway (i.e. loss-of-function mutations in PTCH1 or gain-offunction mutations in SMO) have not been identified in independent sequencing efforts neither in human nor in mouse ACP, suggesting that the SHH pathway may be activated in a paracrine manner (Theunissen \& de Sauvage 2009). Here, we extend these observations by demonstrating the presence of SHH protein within the beta-catenin-accumulating cell clusters, hence reinforcing the idea that the SHH pathway is activated in a liganddependent fashion. Of relevance, we have recently shown that these clusters contain senescent cells and act as signalling hubs within the tumours by activating the expression of numerous secreted factors, including $\mathrm{SHH}$, FGF, EGF, BMP and TGF beta among others (GonzalezMeljem et al. 2017, Apps et al. 2018).

We show that treatment with vismodegib leads to accelerated tumourigenesis with tumours showing an elevated proliferation index, increased clonogenic potential in vitro and enhanced vascularity. In concordance with our preclinical data, research in mouse models of other human cancers, in which the activation of the SHH pathway is also ligand dependent, has revealed that the inhibition of this pathway (e.g. using vismodegib) is protumourigenic. For instance, the inhibition of the $\mathrm{SHH}$ pathway in pancreatic ductal adenocarcinoma (PDAC) murine models either chemically or genetically promotes tumour cell proliferation, undifferentiated phenotypes as well as increased vascularity, resulting in greater tumour burden and shorter survival (Lee et al. 2014, Rhim et al. 2014). Similarly, SHH pathway inhibition in colorectal cancer (CRC) murine models leads to higher numbers of cells with tumour-initiating potential and accelerated tumour formation (Madison et al. 2005, Gerling et al. 2016). Not unexpectedly, the inhibition of the hedgehog pathway in human PDAC and CRC was shown to yield rather disappointing results and patients either did not respond or, even worse, showed signs of faster cancer progression (Berlin et al. 2013, Catenacci et al. 2015, Ko et al. 2016). Moreover, a clinical trial using saridegib (an SMO inhibitor also known as IPI-926) in patients with PDAC was stopped due to increased tumourigenesis in the drug-treated group relative to the controls (Madden 2012, Rimkus et al. 2016) (http://investors.infi.com/static-files/ a2cbb418-8048-4f1f-94cc-dbbff91245be).

A limitation of the research presented here is the absence of corroborating genetic data to further elucidate the possible mechanisms by which $\mathrm{SHH}$ pathway inhibition leads to increased tumourigenesis in ACP. Unfortunately, Hes $1^{\text {Cre/+; }}$ Shh $h^{\text {flox/- }}$ mice die at birth, which prevents such genetic study (i.e. the Hesx 1 Cre/+; Ctnnb1 10xex3/+;Shhflox/- mice cannot be generated) (Carreno et al. 2017). Although ACP cellular models have been used, these have not been molecularly characterised and in our hands, the CTNNB1 mutations that characterise the ACP tumours are lost in the culture cells. Nonetheless, our cellular and molecular characterisation suggest that common mechanisms underlie the protumourigenic effects of SHH pathway inhibition in ACP, PDAC and CRC. We propose that in addition to the angiogenic effects, such inhibition prevents the exit of the cell cycle, resulting in higher numbers of proliferative tumour cells and accelerated tumourigenesis (Fig. 3G). In summary, using a clinically approved and widely employed SMO inhibitor in both the Hes $\times 1^{\text {Crel+ } ; \text { Ctnnb } 1 \text { loxex } 3 /+}$ mice and a human xenograft model, our research demonstrates that the inhibition of the SHH pathway has a tumour-promoting effect. We conclude that the use of vismodegib, and potentially other SMO inhibitors may be contraindicated in ACP patients.

\section{Declaration of interest}

The authors declare that there is no conflict of interest that could be perceived as prejudicing the impartiality of the research reported.

\section{Funding}

Funding for this research was provided by Cancer Research UK, Children's Cancer and Leukaemia Group, Children with Cancer UK (15/190), 
MRC (MR/M125/1), Brain Tumour Charity (SIGNAL and EVEREST), Great Ormond Street Hospital Children's Charity, Morgan Adams Foundation and National Institute of Health Research Biomedical Research Centre at Great Ormond Street Hospital for Children NHS Foundation Trust and University College London. The authors thank CR-UK support to the Cancer Imaging Centre at The Institute of Cancer Research and The Royal Marsden Hospital in association with the MRC and Department of Health (England) (C1060/A16464). S H is supported by a Wellcome Trust PhD Fellowship. J R A is supported by a Cancer Research UK Clinical Research Training Fellowship. J P M-B is a Great Ormond Street Hospital for Children's Charity Principal Investigator.

\section{Acknowledgements}

The authors are grateful to Dr Dale Moulding for the invaluable help in microscopy. They would like to thank the patients, their families and clinicians who have donated tissues to research.

\section{References}

Andoniadou CL, Signore M, Sajedi E, Gaston-Massuet C, Kelberman D, Burns AJ, Itasaki N, Dattani M \& Martinez-Barbera JP 2007 Lack of the murine homeobox gene Hesx1 leads to a posterior transformation of the anterior forebrain. Development 134 1499-1508. (https://doi.org/10.1242/dev.02829)

Andoniadou CL, Gaston-Massuet C, Reddy R, Schneider RP, Blasco MA, Le Tissier P, Jacques TS, Pevny LH, Dattani MT \& Martinez-Barbera JP 2012 Identification of novel pathways involved in the pathogenesis of human adamantinomatous craniopharyngioma. Acta Neuropathologica 124 259-271. (https://doi.org/10.1007/s00401-0120957-9)

Andoniadou CL, Matsushima D, Mousavy Gharavy SN, Signore M, Mackintosh AI, Schaeffer M, Gaston-Massuet C, Mollard P, Jacques TS, Le Tissier P, et al. 2013 Sox2(+) stem/progenitor cells in the adult mouse pituitary support organ homeostasis and have tumor-inducing potential. Cell Stem Cell 13 433-445. (https://doi. org/10.1016/j.stem.2013.07.004)

Apps JR, Carreno G, Gonzalez-Meljem JM, Haston S, Jani N, Holsken A, Pettorini B, Beynon JR, Suimpson DM, Fraser HC, et al. 2018 Tumour compartment transcriptomics demonstrate the activation of inflammatory and odontogenic programmes in human adamantinomatous craniopharyngioma and identify novel therapeutic targets. Acta Neuropathologica 135 755-777. (https://doi. org/10.1007/s00401-018-1830-2)

Berlin J, Bendell JC, Hart LL, Firdaus I, Gore I, Hermann RC, Mulcahy MF, Zalupski MM, Mackey HM, Yauch RL, et al. 2013 A randomized phase II trial of vismodegib versus placebo with FOLFOX or FOLFIRI and bevacizumab in patients with previously untreated metastatic colorectal cancer. Clinical Cancer Research 19 258-267. (https://doi.org/10.1158/1078-0432.CCR-12-1800)

Boult JKR, Apps JR, Holsken A, Hutchinson JC, Carreno G, Danielson LS, Smith LM, Bauerte T, Buslei R, Buchfelder M, et al. 2018 Preclinical transgenic and patient-derived xenograft models recapitulate the radiological features of human adamantinomatous craniopharyngioma. Brain Pathology 28 475-483. (https://doi. org/10.1111/bpa.12525)

Brastianos PK, Taylor-Weiner A, Manley PE, Jones RT, Dias-Santagata D, Thorner AR, Lawrence MS, Rodriguez FJ, Bernardo LA, Schubert L, et al. 2014 Exome sequencing identifies BRAF mutations in papillary craniopharyngiomas. Nature Genetics 46 161-165. (https://doi. org/10.1038/ng.2868)
Buslei R, Nolde M, Hofmann B, Meissner S, Eyupoglu IY, Siebzehnrubl F, Hahnen E, Kreutzer J \& Fahlbusch R 2005 Common mutations of beta-catenin in adamantinomatous craniopharyngiomas but not in other tumours originating from the sellar region. Acta Neuropathologica 109 589-597. (https://doi.org/10.1007/s00401-0051004-x)

Carreno G, Apps JR, Lodge EJ, Panousopoulos L, Haston S, GonzalezMeljem JM, Hahn H, Andoniadou CL \& Martinez-Barbera JP 2017 Hypothalamic sonic hedgehog is required for cell specification and proliferation of LHX3/LHX4 pituitary embryonic precursors. Development 144 3289-3302. (https://doi.org/10.1242/dev.153387)

Catenacci DVT, Junttila MR, Karrison T, Bahary N, Horiba MN, Nattam SR, Marsh R, Wallace J, Kozloff M, Rajdev L, et al. 2015 Randomized phase Ib/II study of gemcitabine plus placebo or vismodegib, a hedgehog pathway inhibitor, in patients With metastatic pancreatic cancer. Journal of Clinical Oncology 33 4284-4292. (https://doi.org/10.1200/JCO.2015.62.8719)

De Smaele E, Ferretti E \& Gulino A 2010 Vismodegib, a small-molecule inhibitor of the hedgehog pathway for the treatment of advanced cancers. Current Opinion in Investigational Drugs 11 707-718.

Donson AM, Apps JR, Greisinger AM, Amani V, Witt DA, Anderson RCE, Niazi TN, Grant G, Souweidane M, Johnson JM, et al. 2017 Molecular analyses reveal inflammatory mediators in the solid component and cyst fluid of human adamantinomatous craniopharyngioma. Journal of Neuropathology and Experimental Neurology 76 779-788. (https://doi.org/10.1093/jnen/nlx061)

Gaston-Massuet C, Andoniadou CL, Signore M, Jayakody SA, Charolidi N, Kyeyune R, Vernay B, Jacques TS, Taketo MM, Le Tissier P, et al. 2011 Increased Wingless (Wnt) signaling in pituitary progenitor/stem cells gives rise to pituitary tumors in mice and humans. PNAS 108 11482-11487. (https://doi.org/10.1073/ pnas.1101553108)

Gerling M, Buller NVJA, Kirn LM, Joost S, Frings O, Englert B, Bergstrom A, Kuiper RV, Blaas L, Wielenga MCB, et al. 2016 Stromal Hedgehog signalling is downregulated in colon cancer and its restoration restrains tumour growth. Nature Communications $\mathbf{7} 12321$. (https://doi.org/10.1038/ncomms12321)

Gomes DC, Jamra SA, Leal LF, Colli LM, Campanini ML, Oliveira RS, Martinelli CE, Elias PCL, Moreira AC, Machado HR, et al. 2015 Sonic Hedgehog pathway is upregulated in adamantinomatous craniopharyngiomas. European Journal of Endocrinology 172 603-608. (https://doi.org/10.1530/EJE-14-0934)

Gonzalez-Meljem JM, Haston S, Carreno G, Apps JR, Pozzi S, Stache C, Kaushal G, Virasami A, Panousopoulos L, Mousavy-Gharavy SN, et al. 2017 Stem cell senescence drives age-attenuated induction of pituitary tumours in mouse models of paediatric craniopharyngioma. Nature Communications 8 1819. (https://doi.org/10.1038/s41467-01701992-5)

Gump JM, Donson AM, Birks DK, Amani VM, Rao KK, Griesinger AM, Kleinschmidt-Demasters BK, Johnston JM, Anderson RCE, Rosenfeld A, et al. 2015 Identification of targets for rational pharmacological therapy in childhood craniopharyngioma. Acta Neuropathologica Communications 3 30. (https://doi.org/10.1186/ s40478-015-0211-5)

Harada N, Tamai Y, Ishikawa T, Sauer B, Takaku K, Oshima M, Taketo MM, Miyoshi H, Murai N \& Oshima H 1999 Intestinal polyposis in mice with a dominant stable mutation of the betacatenin gene. ЕМBO Journal 18 5931-5942. (https://doi.org/10.1093/ emboj/18.21.5931)

Haston S, Pozzi S, Carreno G, Manshaei S, Panousopoulos L, GonzalezMeljem JM, Apps JR, Virasami A, Thavaraj S, Gutteridge A, et al. 2017 MAPK pathway control of stem cell proliferation and differentiation in the embryonic pituitary provides insights into the pathogenesis of papillary craniopharyngioma. Development 144 2141-2152. (https://doi.org/10.1242/dev.150490) https://erc.bioscientifica.com https://doi.org/10.1530/ERC-18-0538 (c) 2019 The authors Published by Bioscientifica Ltd. Printed in Great Britain

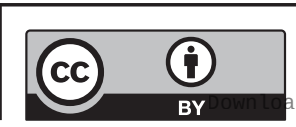

This work is licensed under a Creative Commons Attribution 4.0 International License. ded from Bioscientifica,com at 04/26/2023 07:24:13AM 
Holsken A, Sill M, Merkle J, Schweizer L, Buchfelder M, Flitsch J, Fahlbusch R, Metzler M, Kool M, Pfister SM, et al. 2016 Adamantinomatous and papillary craniopharyngiomas are characterized by distinct epigenomic as well as mutational and transcriptomic profiles. Acta Neuropathologica Communications 420 . (https://doi.org/10.1186/s40478-016-0287-6)

Karavitaki N \& Wass JAH 2008 Craniopharyngiomas. Endocrinology and Metabolism Clinics of North America 37 173-193. (https://doi. org/10.1016/j.ecl.2007.10.012)

Karp NA, Meehan TF, Morgan H, Mason JC, Blake A, Kurbatova N, Smedley D, Jacobsen J, Mott RF, Iyer V, et al. 2015 Applying the ARRIVE guidelines to an in vivo database. PLOS Biology 13 e1002151. (https://doi.org/10.1371/journal.pbio.1002151)

Kato K, Nakatani Y, Kanno H, Inayama Y, Ijiri R, Nagahara N, Miyake T, Tanaka M, Ito Y, Aida N, et al. 2004 Possible linkage between specific histological structures and aberrant reactivation of the Wnt pathway in adamantinomatous craniopharyngioma. Journal of Pathology $\mathbf{2 0 3}$ 814-821. (https://doi.org/10.1002/path.1562)

Ko AH, Loconte N, Tempero MA, Walker EJ, Kate Kelley R, Lewis S, Chang WC, Kantoff E, Vannier MW, Catenacci DV, et al. 2016 A phase I study of FOLFIRINOX plus IPI-926, a hedgehog pathway inhibitor, for advanced pancreatic adenocarcinoma. Pancreas $\mathbf{4 5}$ 370-375. (https://doi.org/10.1097/MPA.0000000000000458)

Lee JJ, Perera RM, Wang H, Wu DC, Liu XS, Han S, Fitamant J, Jones PD, Ghanta KS, Kawano, et al. 2014 Stromal response to Hedgehog signaling restrains pancreatic cancer progression. PNAS 111 E3091-E3100.

Madden JI 2012 Infinity reports update from Phase 2 study of Saridegib plus gemcitabine in patients with metastatic pancreatic cancer. In Business Wire. New York, NY, USA: Business Wire Inc. (available at: https://www.businesswire.com/news/home/20120127005146/en/ Infinity-Reports-Update-Phase-2-Study-Saridegib)

Madison BB, Braunstein K, Kuizon E, Portman K, Qiao XT \& Gumucio DL 2005 Epithelial hedgehog signals pattern the intestinal crypt-villus axis. Development 132 279-289. (https://doi.org/10.1242/ dev.01576)

Muller HL, Merchant TE, Puget S \& Martinez-Barbera JP 2017 New outlook on the diagnosis, treatment and follow-up of childhoodonset craniopharyngioma. Nature Reviews Endocrinology 13 299-312. (https://doi.org/10.1038/nrendo.2016.217)

Rhim AD, Oberstein PE, Thomas DH, Mirek ET, Palermo CF, Sastra SA, Dekleva EN, Saunders T, Becerra CP, Tattersall I, et al. 2014 Stromal elements act to restrain, rather than support, pancreatic ductal adenocarcinoma. Cancer Cell 25 735-747. (https://doi.org/10.1016/j. ccr.2014.04.021)

Rimkus TK, Carpenter RL, Qasem S, Chan M \& Lo HW 2016 Targeting the sonic hedgehog signaling pathway: review of smoothened and GLI inhibitors. Cancers 8 E22. (https://doi.org/10.3390/ cancers8020022)

Sekine S, Shibata T, Kokubu A, Morishita Y, Noguchi M, Nakanishi Y, Sakamoto M \& Hirohashi S 2002 Craniopharyngiomas of adamantinomatous type harbor beta-catenin gene mutations. American Journal of Pathology 161 1997-2001. (https://doi. org/10.1016/S0002-9440(10)64477-X)

Sekulic A, Migden MR, Oro AE, Dirix L, Lewis KD, Hainsworth JD, Solomon JA, Yoo S, Arron ST, Friedlander PA, et al. 2012 Efficacy and safety of vismodegib in advanced basal-cell carcinoma. New England Journal of Medicine 366 2171-2179. (https://doi.org/10.1056/ NEJMoa1113713)

Sekulic A, Migden MR, Basset-Seguin N, Garbe C, Gesierich A, Lao CD, Miller C, Mortier L, Murrell DF, Hamid O, et al. 2017 Long-term safety and efficacy of vismodegib in patients with advanced basal cell carcinoma: final update of the pivotal ERIVANCE BCC study. BMC Cancer 17 332. (https://doi. org/10.1186/s12885-017-3286-5)

Stache C, Holsken A, Schlaffer SM, Hess A, Metzler M, Frey B, Fahlbusch R, Flitsch J, Buchfelder M \& Buslei R 2015 Insights into the infiltrative behavior of adamantinomatous craniopharyngioma in a new xenotransplant mouse model. Brain Pathology 25 1-10. (https://doi.org/10.1111/bpa.12148)

Theunissen J-W \& de Sauvage FJ 2009 Paracrine Hedgehog signaling in cancer. Cancer Research 69 6007-6010. (https://doi.org/10.1158/00085472.CAN-09-0756)

Wong H, Alicke B, West KA, Pacheco P, La H, Januario T, Yauch RL, De Sauvage FJ \& Gould SE 2011 Pharmacokinetic-pharmacodynamic analysis of vismodegib in preclinical models of mutational and ligand-dependent Hedgehog pathway activation. Clinical Cancer Research 17 4682-4692. (https://doi.org/10.1158/1078-0432.CCR-110975)

Workman P, Aboagye EO, Balkwill F, Balmain A, Bruder G, Chaplin DJ, Double JA, Everitt J, Farningham DA, Glennie MJ, et al. 2010 Guidelines for the welfare and use of animals in cancer research. British Journal of Cancer 102 1555-1577. (https://doi.org/10.1038/sj. bjc.6605642)

Received in final form 10 January 2019

Accepted 15 January 2019

Accepted Preprint published online 15 January 2019 (c) 2019 The authors Published by Bioscientifica Ltd. Printed in Great Britain
This work is licensed under a Creative Commons Attribution 4.0 International License. ded from Bioscientifica.com at 04/26/2023 07:24:13AM 